\title{
Igneous sill and finger emplacement mechanism in shale- dominated formations: a field study at Cuesta del Chihuido, Neuquén Basin, Argentina
}

\author{
Juán B. Spacapan ${ }^{1}$, Olivier Galland ${ }^{2 *}$, Héctor A. Leanza ${ }^{3 *}$ \& Sverre Planke S,5 $^{4,5}$ \\ ${ }^{1}$ Universidad Nacional de La Plata-CONICET-Fundación YPF, 1900 La Plata, Argentina \\ ${ }^{2}$ Physics of Geological Processes (PGP), Department of Geosciences, University of Oslo, N-0316, Oslo, Norway \\ ${ }^{3}$ Museo Argentino de Ciencias Naturales-CONICET, 1405 Buenos Aires, Argentina \\ ${ }^{4}$ Volcanic Basin Petroleum Research (VBPR), Oslo Science Park, Gaustadalléen 21, N-0349 Oslo, Norway \\ ${ }^{5}$ Centre for Earth Evolution and Dynamics (CEED), Department of Geosciences, University of Oslo, N-0315, Oslo, Norway \\ *Correspondence: olivier.galland@geo.uio.no
}

\begin{abstract}
Seismic reflection data and field observations have revealed the presence of voluminous igneous sill complexes emplaced into organic-rich shale formations in sedimentary basins worldwide. Damage and structures associated with sills have major implications for fluid flow through basins. Constraining the distribution of these structures requires a good understanding of the sill emplacement mechanism. However, most mechanical models of sill emplacement assume elastic host behaviour, whereas shale is expected to deform inelastically. This contradiction calls for new field observations to better constrain sill emplacement mechanisms. In this paper, we report on detailed field observations of spectacularly exposed fingers and a sill emplaced in shale at Cuesta del Chihuido, in the Neuquén Basin, Argentina. Exceptional outcrop conditions allow detailed descriptions of both (1) the entire cross-section of the intrusions, and (2) the deformation structures accommodating intrusion propagation in the host rock. All intrusions exhibit irregular, blunt or rectangular tips. The structures accommodating the tip propagation are systematically compressional, including reverse faults, folding and imbricate thrust system. Our observations suggest that the studied intrusions have propagated by pushing the host rock ahead, as a viscous indenter. Our observations suggest that the viscous indenter model is probably a dominant mechanism of sill emplacement in shale.
\end{abstract}

Received 17 May 2016; revised 16 October 2016; accepted 6 November 2016

Igneous sheet intrusions, such as dykes and sills, represent dominant conduits through the Earth's crust (e.g. Walker 1975; Rubin 1995; Petford et al. 2000; Cartwright \& Hansen 2006; Magee et al. 2016). In particular, the last two decades of research have highlighted that voluminous sill networks and laccoliths facilitate extensive lateral and vertical magma transport and emplacement in sedimentary basins worldwide, such as offshore Norway (e.g. Svensen et al. 2004; Planke et al. 2005), the Karoo Basin, South Africa (Chevallier \& Woodford 1999; Polteau et al. 2008a,b; Galerne et al. 2011), the Rockall Basin, offshore Ireland (Thomson 2004; Thomson \& Hutton 2004; Hansen \& Cartwright 2006b; Magee et al. 2014), the Faeroe-Shetland Basin (Trude et al. 2003), the Neuquén Basin, Argentina (Rossello et al. 2002; Rodriguez Monreal et al. 2009; Witte et al. 2012) and offshore Australia (Symonds et al. 1998; Jackson et al. 2013; Magee et al. 2013). These sill complexes have major impacts on the evolution of sedimentary basins as they induce organic matter maturation and fluid migration (Aarnes et al. 2011), which can cause overmaturation of the source rock and potentially lead to the release of large volumes of greenhouse gases and affect global climate (Svensen et al. 2004); furthermore, they may trigger the formation of forced folds (Trude et al. 2003; Hansen \& Cartwright 2006b; Jackson et al. 2013) that can be hydrocarbon traps; and they can be fractured hydrocarbon reservoirs (Rodriguez Monreal et al. 2009; Witte et al. 2012) and ground-water aquifers (Chevallier et al. 2001, 2004). Understanding the emplacement mechanisms of sill complexes is thus of paramount importance for constraining the structures and evolutions of volcanic basins.

Our understanding of sill and laccolith emplacement mechanism is still unconstrained, and various contradicting models exist. The most commonly accepted model assumes that sills, on the basis of their sheet shape and low thickness-to-length aspect ratios, are hydraulic fractures (Fig. 1a) (Hubbert \& Willis 1957; Lister \& Kerr 1991; Rubin 1995). Consequently, most theoretical and numerical models of sill and laccolith emplacement account for purely elastic host rock (Pollard 1973, 1987; Lister 1990a,b; Gudmundsson et al. 1999; Menand \& Tait 2002; Rivalta et al. 2005; Taisne \& Tait 2009; Maccaferri et al. 2010; Bunger \& Cruden 2011; Galland \& Scheibert 2013). Rubin (1993) recognized that tensile purely elastic fracture models were too simplified, and he proposed an extension of this model by introducing a Barenblatt-type cohesive plastic zone at the intrusion tip (Fig. 1b).

In many basins, igneous sills and laccoliths were preferentially emplaced into formations of certain lithologies, often shale (e.g. Pollard et al. 1975; Rossello et al. 2002; Thomson 2007; Rodriguez Monreal et al. 2009; Schofield et al. 2010; Witte et al. 2012; Magee et al. 2014). Shale rocks are known to have the ability to easily deform in an inelastic manner, which suggests that the tensile elastic fracture models might not be relevant to explaining the emplacement of most sills (Schofield et al. 2012a, and references therein). Pollard (1973) proposed two mechanisms of intrusion tip propagation accommodated by inelastic deformation of the host rock: brittle and ductile faulting (Fig. 1c and d). Pollard et al. (1975) suggested that the growth of igneous fingers into their host rock occurs as a Saffman-Taylor instability (Saffman \& Taylor 1958); that is, the instability of the interface between an intruding magma and its viscous host rock. Schofield et al. (2010, 2012a) and Jackson et al. (2013) suggested instead that the propagation of magma is accommodated by fluidization of the host rock (Fig. 1e). Finally, Mathieu et al. (2008) and Abdelmalak et al. (2012) proposed that 


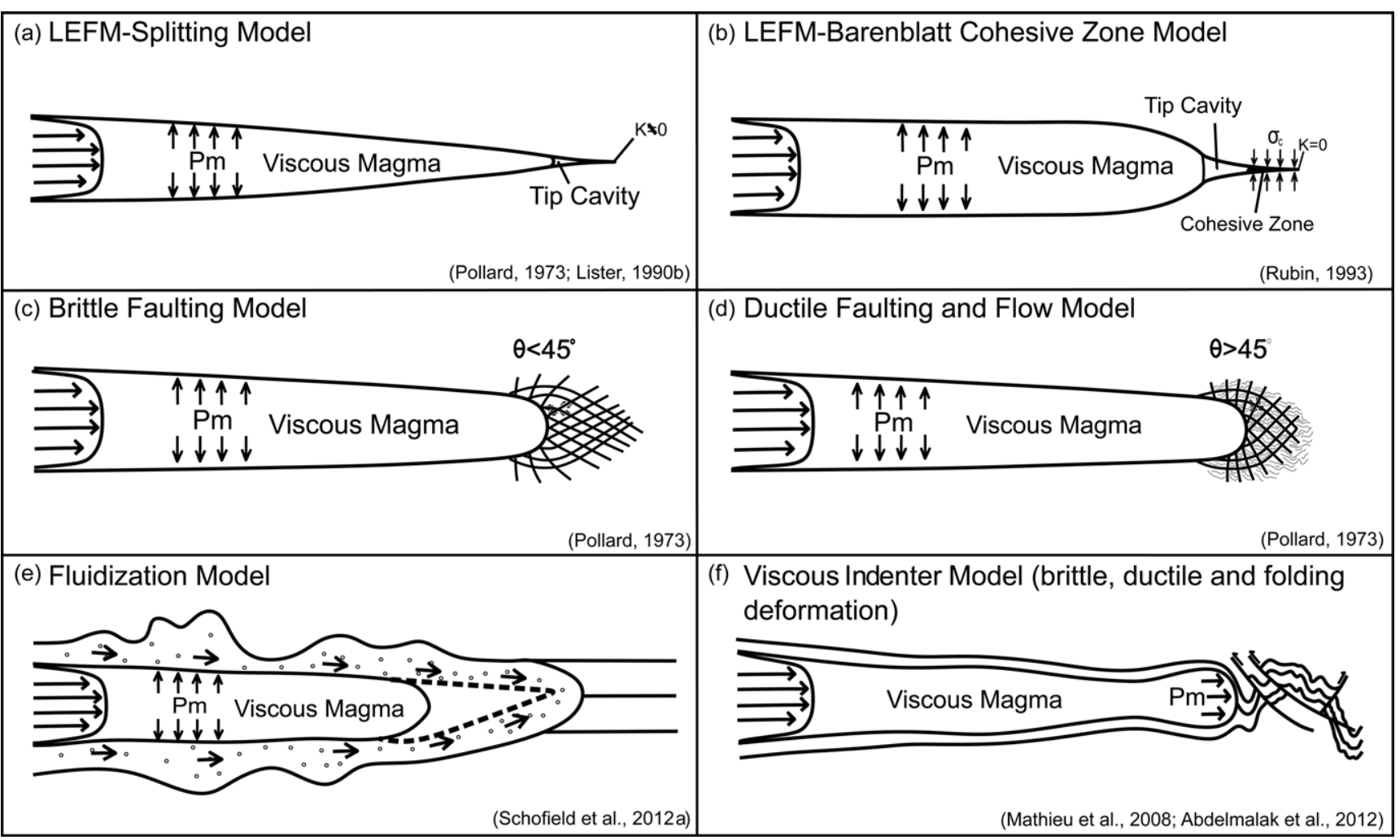

Fig. 1. Sketches of sill emplacement models. (a) Linear elastic fracture mechanics-splitting model (e.g. Pollard 1973; Lister 1990b). The overpressure (Pm) in the magma pushes on the sill's walls. The sill tip is expected to be sharp, and its propagation occurs by tensile opening (mode I fracturing). According to Lister (1990b), the magma viscosity is such that it does not allow the magma to flow toward the tip, leading to the formation of a tip cavity filled with fluids derived from the magma or the country rock. Tip propagation is controlled by the stress intensity factor $K$. (b) Elastic tensile fracture with a Barenblatt cohesive zone (Rubin 1993). This model has similarities to the former one, except that the tip propagation is controlled by the cohesion $\sigma_{\mathrm{c}}$ within the cohesive zone. (c) Brittle faulting model (Pollard 1973). In this model, the magma pushes its host rock, which fails and forms brittle faults, along which the magma subsequently propagates. (d) Ductile faulting model (Pollard 1973). Similarly to the brittle faulting model, the magma pushes its host rock, which in this case fails and forms ductile faults, along which the magma subsequently propagates. It should be noted that the angles of the shear planes differ from those expected from the brittle faulting model. (e) Fluidization model with two end-members (Schofield et al. 2010, 2012a): (i) 'thermal' fluidization, which is continuous fluidization resulting from rapid boiling of pore-fluids as magma intrudes the host rock; (2) 'triggered' fluidization, which occurs locally when heated pore-fluids are locally unconfined by opening of, for example, pre-existing fractures. (f) Viscous indenter model (Merle \& Donnadieu 2000; Mathieu et al. 2008; Abdelmalak et al. 2012). In this model, the shear stresses owing to highly viscous magma flow lead to shear (brittle and ductile) failure of the host rock. In this mode, the magma appears as rigid as, or even more rigid than, the host rock.

the viscous indenter model (Fig. 1f), defined for the protrusion of viscous magma through volcanic edifices (Donnadieu \& Merle 1998; Merle \& Donnadieu 2000) can also be applied to the propagation and emplacement of magma of relatively low viscosity in elasto-plastic rocks.

The diversity of the above-listed emplacement models highlights our limited understanding of sill emplacement mechanisms. Testing the relevance of these models requires the integration of detailed observations of both (1) the entire morphology of a sheet intrusion, specifically the sill tips, and (2) the structures that accommodate intrusion propagation. In this paper, we present the results of detailed structural mapping of a high-quality outcrop at Cuesta del Chihuido, located in the Neuquén Basin, Argentina, which exhibits several igneous intrusions (one sill, five fingers and one dyke), their contacts and the structures in their finely layered sedimentary host rock (alternating shale and calcareous mudstone layers). This exceptional outcrop allows us to correlate sill tip morphologies with their associated small-scale deformation patterns in the host rock, constraining the dynamics of igneous intrusion propagation.

\section{Sill emplacement mechanisms}

This section reviews existing models of sill emplacement. In particular, it highlights how each model is associated with contrasting shapes of intrusion tips and structures in the host rock.
This will facilitate the direct comparison between our observations and the structures expected from existing models of sill emplacement.

\section{Tensile elastic fracture-splitting model}

The tensile elastic fracture model, commonly used to model the emplacement of sheet-shaped dykes and sills (e.g. Pollard 1987; Takada 1990; Lister \& Kerr 1991; Menand \& Tait 2002; Bunger \& Cruden 2011; Kavanagh et al. 2013), assumes that the host rock behaves as purely linear elastic solid (Fig. 1a). In this model, the tip propagates by tensile opening of the host rock (also termed splitting model by Pollard 1973), such that the opening vector is dominantly perpendicular to the contacts. The displaced host rock layers should therefore mimic the intrusion shape, and in the case of concordant sills the strata should have the same thickness along the sill and ahead of the sill tip. This also implies that the displaced layers are expected to have constant thickness along-strike.

The LEFM (Linear Elastic Fracture Mechanics)-splitting model assumes that fracture tips are sharp and thin (Fig. 1a); thus Lister $(1990 b)$ highlighted that the magma viscosity is such that it is unable to flow in the narrow, sharp tips of dykes and sills. Based only on this theoretical argument, he inferred the presence of a tip cavity, between the magma front and the intrusion tip, filled with volatiles exsolved from either the magma or the host rock (Fig. 1a). 


\section{LEFM-Barenblatt cohesive zone model}

This model is an extension of the former one and accounts for a plastic, cohesive zone at the intrusion tip (Fig. 1b) (Rubin 1993). In this model, intrusion propagation occurs by tensile failure; however, the model predicts the occurrence of compressional stresses at the vicinity of the intrusion tip owing to the suction induced by the presence of a tip cavity. This tip suction is expected to pull the host rock ahead of the sill tip toward the tip (fig. 12 of Rubin 1993).

Although the model of Rubin (1993) considers that the intrusion tips are sharp and propagate by tensile failure, it assumes that tip blunting can happen as a late phenomenon, which occurs when (1) sills are significantly large, such that the supposed tip cavity becomes long enough to allow host rock faulting and folding near the intrusion tip, and/or (2) the propagation halts, such that the supposed tip cavity disappears and the magma pressure can bend and deform the host rock and widen the intrusion tip.

\section{Fluidization model}

Magma emplaced within sediments brings a considerable amount of heat, which diffuses in the host rock (Aarnes et al. 2011). If the host contains aqueous fluids or organic matter, the diffusing heat can lead to boiling of aqueous fluids (Jamtveit et al. 2004) or cracking of the organic matter (Aarnes et al. 2011), both leading to fluid pressure build-up in the host at the vicinity of the intrusion. The pressure build-up is such that it can trigger fluidization of the host (Nermoen et al. 2010), the transport of which accommodates the emplacement of the magma (Schofield et al. 2010, 2012a; Jackson et al. 2013) (Fig. 1e). Rock fluidization produces incoherent disruption of the fluidized rocks, easily recognizable in the field (Schofield et al. 2012a).

\section{Saffman-Taylor instability model}

By analysing igneous fingers of the Shonkin Sag Sill, Montana, Pollard et al. (1975) suggested that the large thickness-to-length aspect ratios of the fingers, their rounded tips and the evidence of ductile deformation in the host cannot be the result of elastic fracturing. Instead, they proposed that the fingering emplacement process was governed by a Saffman-Taylor instability (Saffman \& Taylor 1958) of an advancing interface between a Newtonian viscous magma and a more viscous Newtonian host rock. In this mechanism, if the initially straight interface between the two fluids is subject to small perturbations, the straight interface is not stable and the lower viscosity fluid produces fingers within the higher viscosity fluid.

\section{Brittle and ductile faulting; viscous indenter}

These models share common features: the host rock ahead of the intrusion tips fails in a shear manner (i.e. is faulted) by the propagation of the magma (Fig. 1c and d). The brittle and ductile faulting models (Pollard 1973) represent two end-member models of host rock deformation; that is, brittle and ductile, respectively. However, they are phenomenologically similar: they account for the push of the magma, which bulldozers the host rock at the intrusion tip, and the structures expected at the tip of the intrusions accommodate compression. The main difference between the two models is the angle of the shear planes to the intrusion plane: $30^{\circ}$ for brittle faulting and $45^{\circ}$ for ductile faulting (Fig. 1).

The brittle and ductile faulting models consider only end-member deformation modes in the host rock, and not the magma dynamics (Pollard 1973). However, the magma viscosity plays a major mechanical role during emplacement (Bunger \& Cruden 2011;
Michaut 2011; Galland et al. 2014), and rock formations can be complex brittle or ductile mechanical systems. This natural complexity is accounted for in the conceptual viscous indenter model (Donnadieu \& Merle 1998; Merle \& Donnadieu 2000; Mathieu et al. 2008; Abdelmalak et al. 2012). This model states that the viscous shear stresses near the tip of a propagating intrusion are high enough to overcome the strength of the host rock (Galland et al. 2014), with the result that the propagating magma pushes its host rock ahead like an indenter with a blunt or rectangular tip. In this model, the deformation associated with tip propagation consists of conjugate shear faults that accommodate shortening of the host ahead of the tip. Such a mechanism has been dominantly applied to viscous magmas; for example, rhyolites (Donnadieu \& Merle 1998; Merle \& Donnadieu 2000). However, very similar features have been inferred for lower viscosity magma intrusions, such as dykes of probably basaltic composition (White et al. 2011) and dykes of probably andesitic composition (Hayashi \& Morita 2003; Roman et al. 2004).

\section{Geological setting}

The Neuquén Basin is located on the eastern side of the Andes in Argentina and central Chile, between $32^{\circ} \mathrm{S}$ and $40^{\circ} \mathrm{S}$ (Fig. 2a). The basin comprises Late Triassic to early Cenozoic sedimentary sequences covering an area of more than $120000 \mathrm{~km}^{2}$, with up to $6000 \mathrm{~m}$ of preserved marine and continental deposits (Gulisano \& Gutiérrez Pleimling 1995; Vergani et al. 1995; Cobbold \& Rossello 2003). The marine sedimentary strata consist mainly of shale, sandstone and carbonate, reflecting the varying depositional environments in the basin through time. Abundant volcanic deposits and intrusive complexes formed during the development of the Andean subduction zone, in particular in the back-arc part of the basin during Eocene and Miocene (Kay et al. 2006). The study area is located at Cuesta del Chihuido $\left(35^{\circ} 44.923^{\prime} \mathrm{S}, 69^{\circ} 35.277^{\prime} \mathrm{W}\right)$, $32 \mathrm{~km}$ south of the city of Malargüe, in southern Mendoza Province (Fig. 2a). There, a high-quality outcrop, exposed by recent renovation of the National Road 40 (Fig. 2c), is located at the western limb of a basement-cored anticline (Fig. 2b). This anticline is located in the hanging wall of the Andean frontal thrust, and is part of the Malargüe fold-and-thrust belt that formed as a result of Mesozoic rift inversion during successive episodes of Cenozoic compressional orogeny (Manceda \& Figueroa 1995; Cobbold \& Rossello 2003; Giambiagi et al. 2009).

The main sedimentary formations exposed at the Cuesta del Chihuido area are the Tordillo, Vaca Muerta, Chachao and Agrio formations (Fig. 2b), which form the Mendoza Group (Uliana et al. 1977; Legarreta et al. 1981). At the studied outcrop, the sedimentary host rock of the studied intrusions is composed of the Agrio Formation only, which is a marine unit deposited in a gentle slope ramp setting, composed of rhythmic carbonate-shale beds (Sagasti 2000, 2005). This last characteristic facilitates to a great extent the interpretation of deformational structures in the sedimentary rocks as a response to magma emplacement. The age of the Agrio Formation, based on ammonite content, is regarded as Late Valanginian-Early Hauterivian (Leanza \& Hugo 1978; Leanza 2009). As a result of Andean tectonics, the exposed sedimentary layers dip gently to the east.

Although the sills are considerably altered (i.e. the original mineralogy is almost not preserved), they are probably of the same andesitic composition as nearby dykes (Spacapan et al. 2016) and sills hosted in the Vaca Muerta Formation below the Chachao Formation, $1.5 \mathrm{~km}$ to the east along the same road (Jamtveit et al. 2011). The age and regional extent of the sills are poorly determined, and at present no radiometric ages are available. However, recent studies suggest that the sills were emplaced as a part of the late Miocene Huincán eruptive episode (between 
(a)

(b)

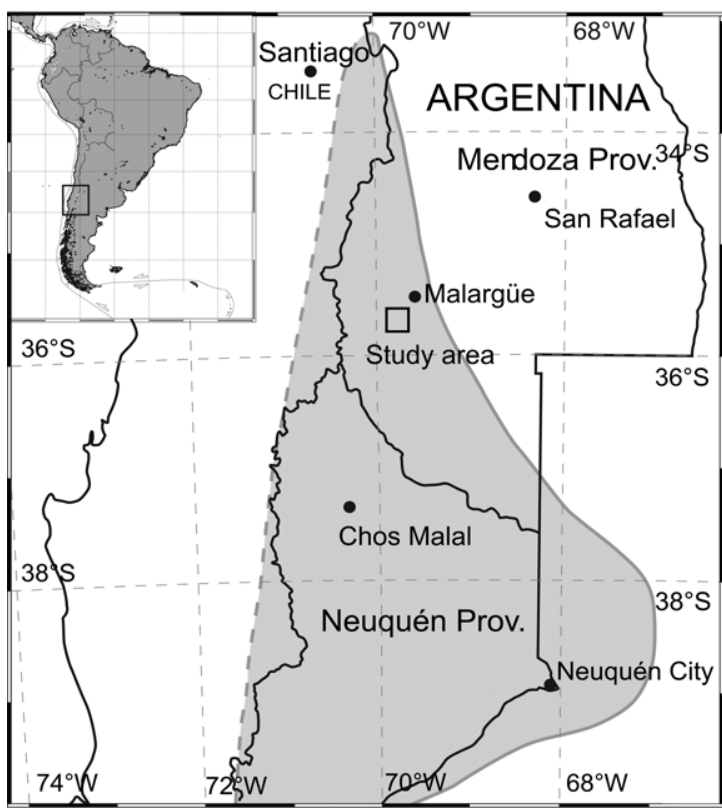

W69 $69^{\circ} 37$

$\mathrm{W} 69^{\circ} 31$

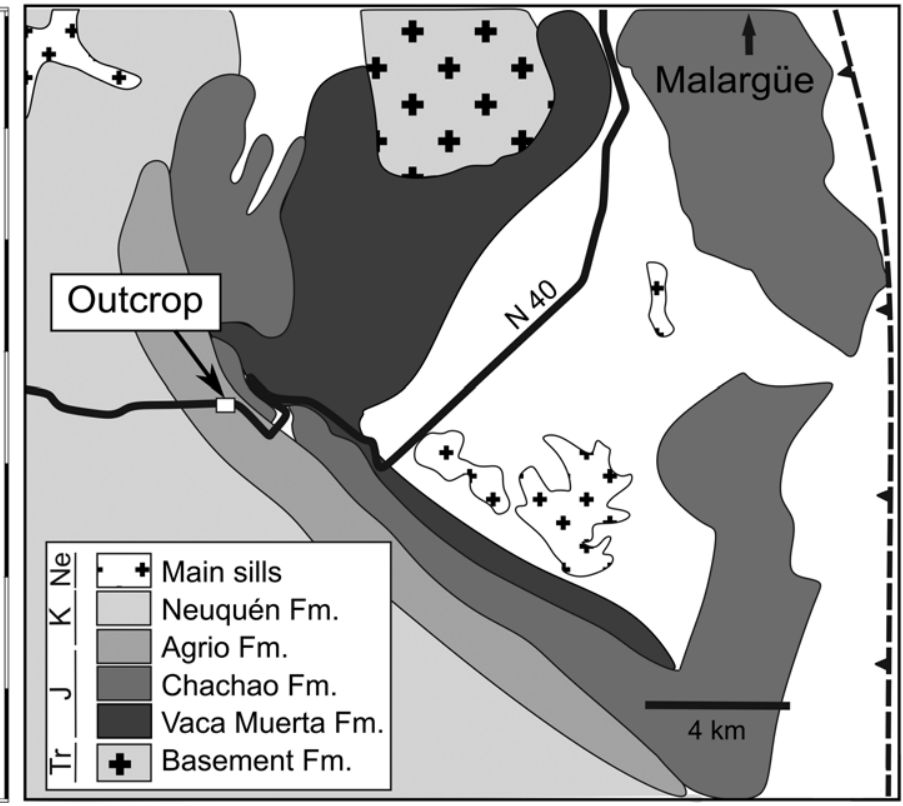

$\mathrm{S} 35^{\circ} 45$

$35^{\circ} 49$

Fig. 2. (a) Regional location of the study area. (b) Simplified geological map showing location of the study area at Cuesta del Chihuido (small white rectangle).

10.5 and 7 Ma; Baldauf et al. 1997; Combina \& Nullo 2005; Nullo et al. 2005). These sills might be of the same age as the nearby hydrocarbon-producing sills intruded into the Vaca Muerta Formation during the Miocene (Rodriguez Monreal et al. 2009; Witte et al. 2012).

\section{Geological observations}

The outcrop at Cuesta del Chihuido exhibits a dyke, a sill and five other intrusions, referred to below as fingers (Fig. 3), as defined and discussed by Pollard et al. (1975) and Schofield et al. (2012a); the fingers are numbered from finger 1 to finger 5. We also note the presence of small $(<0.5 \mathrm{~m})$ rounded intrusions between the sill and finger 5 . The great advantage of the Chihuido outcrop is the prominent layering of the host rocks, which allows detailed mapping of each layer along the entire outcrop. This characteristic is essential for establishing deformation patterns and behaviour of the host rock. To simplify the description of our observations, we assign a letter to each layer, from A (bottom layer) to I (top layer) (Fig. 3). These layers each have different compositions and thicknesses, thus they can be interpreted with very high confidence along the outcrop. Layer A is massive mudstone exposed only to the east of the outcrop (Fig. 3). Layers $\mathrm{B}, \mathrm{D}, \mathrm{E}$ and $\mathrm{H}$ are single calcareous mudstone layers of different thicknesses. Layer $G$ consists of a series of thin stratified mudstone layers. Layer $\mathrm{F}$ is an excellent marker, as it consists of a lower mudstone layer attached to an upper layer of recrystallized carbonate. Finally, layer $\mathrm{C}$ consists of alternating thin mudstone layers and shale layers (Fig. 3).

We took 32 aligned photographs of the outcrop, with 75\% overlap between successive photographs, to produce an orthorectified photograph of the whole outcrop (Fig. 3) using the opensource photogrammetry MicMac software (http://logiciels.ign.fr/? Micmac; see also Pierrot-Deseilligny \& Paproditis 2006; Rosu et al. 2015; Galland et al. 2016). Orthorectifying the images implies that structures in the image are not distorted. We mapped in detail the shapes of the intrusions and the characteristic structures within their host rocks, which can be mapped along the whole outcrop, as illustrated in Figure 3.

\section{Shapes of intrusions}

For clarity, we number the fingers from one to five (Fig. 3) and describe their shapes below. To undertake such an analysis, we divided the Chihuido outcrop into four regions, as indicated by boxes in Figure 3.

The sill (c. $1.3 \mathrm{~m}$ thick) exhibits a sheet shape, with an almost uniform thickness and a slight thickening toward the outcropping tip (middle of outcrop; Fig. 3). Its lower and upper contacts dominantly follow layer $\mathrm{F}$ and layer $\mathrm{G}$, respectively. The tip consists of two lobes (Fig. 4). Finger 3 is in contact with the roof of the sill close to its tip (Figs 3 and 4). From field observations, it is difficult to conclude if finger 3 was connected to the sill, given that a thin sliver of deformed shale is present between the tip and the bottom of the sill. The west tip of finger 3 is thick, with a rectangular shape.

Finger $1(<1 \mathrm{~m}$ thick) is a small intrusion located just below the sill and to the west of the dyke (Figs 3 and 5). Its thickness-to-length aspect ratio (0.5) is large compared with those of the other intrusions of the outcrop, and compared with typical dykes (e.g. Rubin 1995) and sills (McCaffrey \& Petford 1997; Bunger \& Cruden 2011). The upper contact is dominantly parallel to layer $\mathrm{F}$ and the lower contact is parallel to layer E (Fig. 5). The east tip is relatively sharp, whereas the west tip is irregular.

Finger 2 (c. $1 \mathrm{~m}$ thick) intruded at the same stratigraphic level as finger 1, and is located below the sill (Fig. 3). Its upper contact is bounded by layer $\mathrm{F}$, and its lower contact is partly bounded by layer D. It exhibits substantial thickness variations. Both tips are rectangle-shaped with smoothed angles.

Finger $4(<1 \mathrm{~m}$ thick) is located to the west of the sill (Figs 3 and 4). It exhibits a very irregular shape, with a significant increase of thickness from the west side to the east. Its east tip is almost rectangular-shaped, similar to the tips of finger 2 .

Finger 5 (c. $1.5 \mathrm{~m}$ thick) is the largest finger exposed on the Chihuido outcrop. It intruded at the same stratigraphic level as finger 4. Its shape is chaotic, with thin magmatic sheets being connected to a thick central part (Fig. 5). The west tip is very complex and difficult to clearly observe as the geometry of the body is extremely irregular with numerous connected ramifications (Fig. 6). At the east tip of finger 5, we found very local centimetre-scale fluidization features in the host rock. 


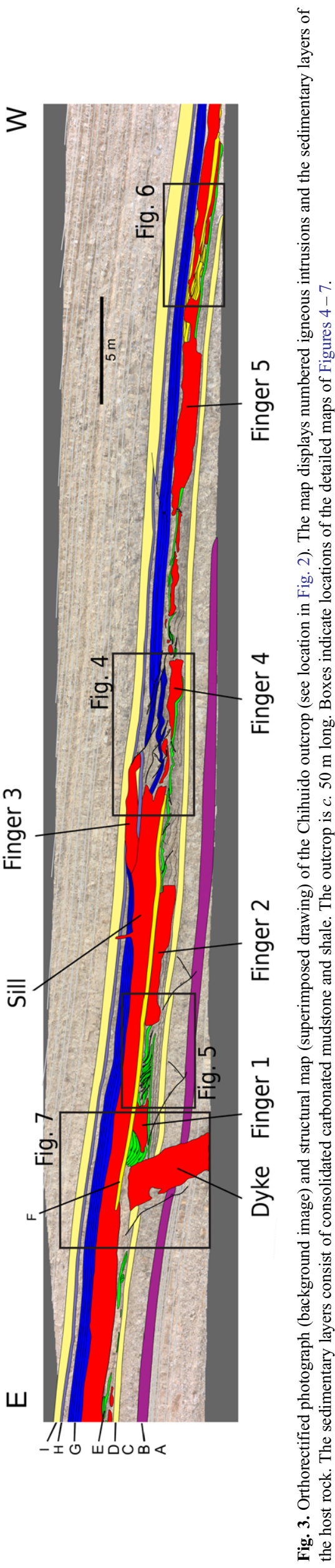

The last main intrusion is the dyke, located below the sill and to the east of finger 1 (Fig. 3). The west wall is regular, whereas the east wall is very irregular, with blocks of the host rock surrounded by the magma (Fig. 7). The dyke thickness overall slightly increases from bottom to top; that is, towards the tip, which is rectangular-shaped, parallel to the layering and to the lower contact of the sill (Fig. 7). Although the dyke tip is close to the sill, we did not observe any connection between them.

\section{Structures in host rock}

In this section, we will describe the observed structures affecting the various layers to establish an outcrop-scale pattern of the host rock deformation. Layers A-D are continuous along most of the outcrop. However, they are locally affected by the complex deformation pattern in the surroundings of the dyke (Fig. 3). First, these four layers are offset $(0.5-1 \mathrm{~m}$ offset) on the two sides of the dyke, with an apparent normal displacement (Fig. 7). Close to the east wall of the dyke, a fault affects layer D with apparent reverse displacement, whereas it affects layer B with small apparent normal displacement (Fig. 7). To the west of the dyke, small reverse faults with vergence to the east offset layers $\mathrm{C}$ and D (Figs 3 and 5).

Layer E (c. $5 \mathrm{~cm}$ thick) exhibits a very complex structure. It appears as a continuous thin layer at the lower contact of finger 2 (Fig. 5) and to the west of finger 5 (Fig. 6). Conversely, this layer is repeated many times as imbricate stacks between the dyke and finger 1 (Fig. 7) and between fingers 1 and 2 (Fig. 5), the contact between each of the repeated layers being a shallow-dipping thrust fault with vergence to the east; that is, the same as the propagation direction of the east tip of finger 2. It should be noted that slices of layer $E$ are steeper towards the tip of finger 2. Interestingly, layer $E$ is totally absent at the location of finger 2, but appears again to the west of it (Fig. 3). Layer E can be followed between fingers 2 and 4, although it is dissected by numerous small reverse faults of variable vergence and folds. Only discontinuous segments of layer E crop out between fingers 4 and 5 (Fig. 3). Layer $\mathrm{E}$ is totally absent under finger 5. It should be noted that the interval between layers $\mathrm{D}$ and $\mathrm{F}$ is thicker to the west of the dyke $(c .1 \mathrm{~m})$; that is, where it hosts fingers 1, 2, 4 and 5, than to the east of the dyke $(c .0 .6 \mathrm{~m})$.

Layer F (c. $10 \mathrm{~cm}$ thick) exhibits similar behaviour. It is absent under the east part of the sill, whereas it is continuous under the sill between its termination and the dyke tip (Fig. 3). Conversely, layer F is absent between the tip of the sill (Fig. 4) and the west tip of finger 5 (Fig. 6). There, it appears repeated many times (Fig. 6). The nature of the contacts between the repeated layers is not clear, but they are probably thrust faults verging to the west; that is, the propagation direction of the west tip of finger 5 .

In most of the outcrop, layer $\mathrm{G}$ (c. $0.7 \mathrm{~m}$ thick) is continuous and parallel to the main intrusions (Fig. 3). However, it appears strongly deformed at the tip of the sill, where it is intensely folded and dissected by numerous reverse faults (Fig. 4). In addition, layer $\mathrm{G}$ is doubled by a low-angle reverse fault above finger 4 (Fig. 4). At the east tip of finger 5, layer $\mathrm{G}$ is also offset by a small reverse fault, which vanishes in layer I (Fig. 3).

Layer $\mathrm{H}(10 \mathrm{~cm}$ thick) is dominantly continuous (Fig. 3). However, finger 3 separates a block of layer $\mathrm{H}$ from layer I (Fig. 4); the apparent displacement associated with emplacement of finger 3 is reverse. Layer $\mathrm{H}$ is also offset by a small-scale reverse fault above the east tip of finger 5 (Fig. 3).

The massive layer I ( $45 \mathrm{~cm}$ thick) is continuous (Fig. 3). Only a small block has been detached through the emplacement of finger 3 (Fig. 4). We also observe a small reverse fault partly affecting layer I above finger 5 (Fig. 3). It should be noted that the interval between layers D and I is thicker where it hosts the sill. This interval has a wedge shape, with a gradual thinning from $c .2 .6 \mathrm{~m}$ thickness to $c$. $1.8 \mathrm{~m}$ thickness (30\% thinning) away from the sill tip (Fig. 3). 


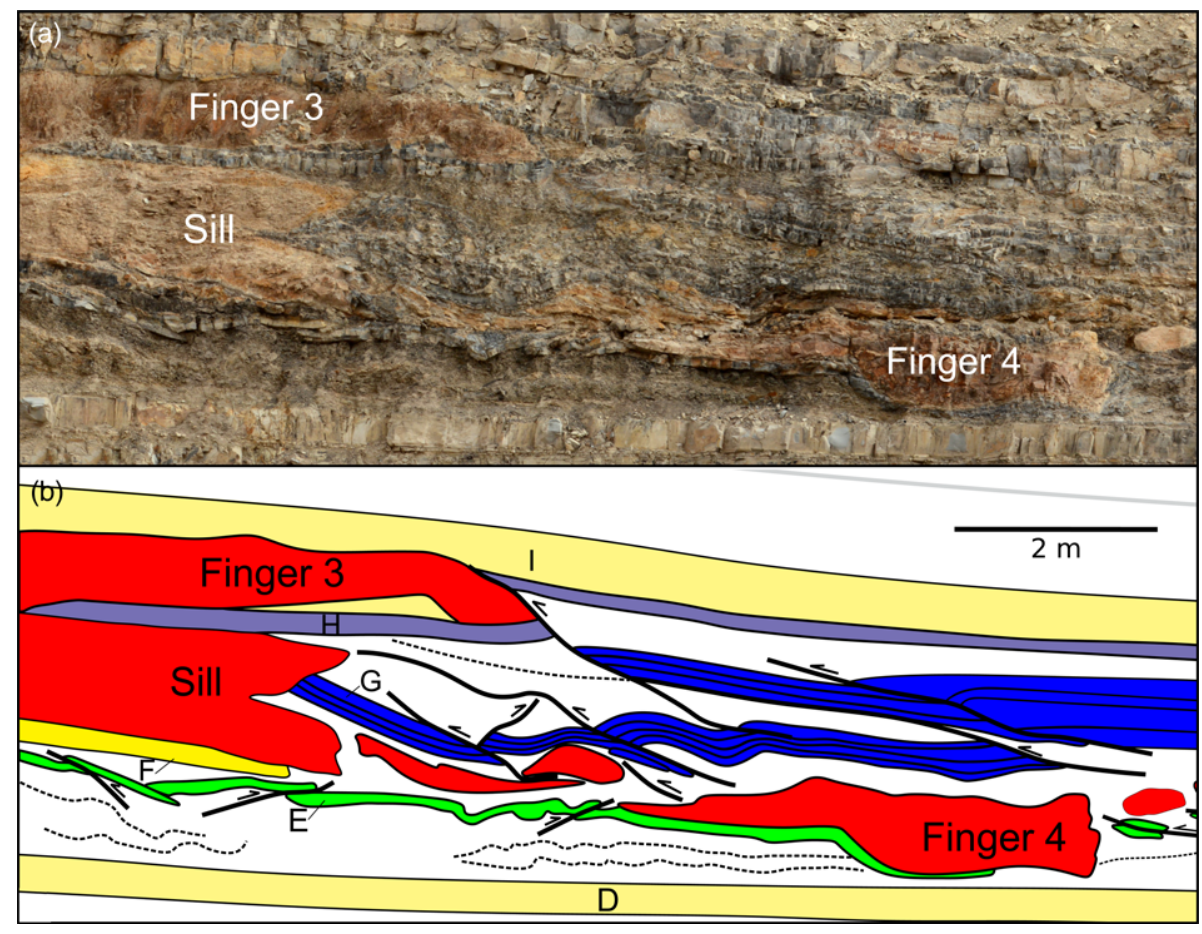

Fig. 4. (a) Detailed orthorectified photograph of the Chihuido outcrop (see location in Fig. 3), displaying fingers 3 and 4 and part of the sill, and the surrounding structures in the host rock. (b) Detailed map of (a), displaying parts of layers D, E, F, G, H and I and their associated structures. The most noticeable feature is the repetitions of layer $\mathrm{G}$.

\section{Interpretation and discussion}

\section{Deformation pattern in the host rock and emplacement processes}

The main advantages of the Chihuido outcrop are (1) its extent, such that entire intrusion cross-sections, from tip to tip, are visible, and (2) the finely layered host rock, which allows precise mapping of structures accommodating the emplacement of intrusions. Our structural maps indicate both brittle (i.e. faulting of the mudstone layers $\mathrm{C}-\mathrm{G}$; Figs $3-7$ ) and ductile (i.e. flow of the shale between the mudstone layers) deformation. Thus both deformation mechanisms can be at work, as discussed by Schofield et al. (2012a). It should be noted that by brittle deformation we mean both open and shear fracturing as defined by Jaeger et al. (2009).

It is noticeable that deformation accommodating emplacement of magma is systematically related to lateral shortening by thrust faulting and/or folding of host rock layers (Figs 3-7). This shortening becomes more extreme ahead of the intrusion tips, where the affected layers are repeated many times as imbricate stacks. Good examples are evident between the dyke and finger 1 (layer E; Fig. 7), between fingers 1 and 2 (layer E; Fig. 5) and ahead of the west tips of the sill (layer G; Figs 3 and 4) and of finger 5 (layer F; Fig. 6). The main vergence of the thrusts causing repetition of the layers is the same as the propagation direction of the nearby finger tips. We notice that shortening occurs at the tips of both the sheetshaped sill and the fingers, suggesting that their emplacement mechanisms are related despite their shape difference.

The shortening at the east tip of finger 2 is such that the affected layer $\mathrm{E}$ is repeated numerous times in imbricate stacks (Fig. 5). The steeper slices of layer E towards the tip of finger 2 suggest that they formed first (Graveleau et al. 2012). Most noticeable is the absence of layer $\mathrm{E}$ where finger 2 crops out (Figs 3 and 5). We infer that the magma emplacement occurred by pushing away parts of the host

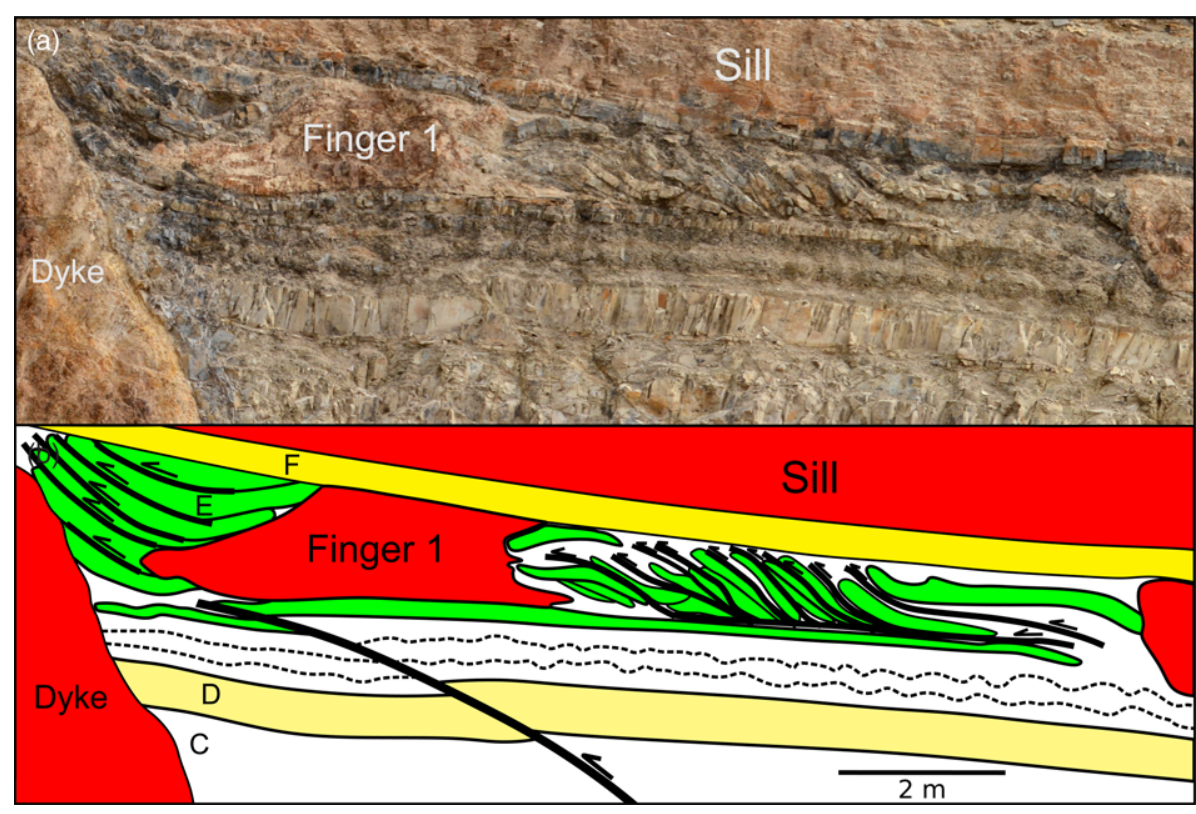

Fig. 5. (a) Detailed orthorectified photograph of the Chihuido outcrop (see location in Fig. 3), displaying finger 1 and parts of finger 2, sill and dyke, and the surrounding structures in the host rock. (b) Detailed map of (a), displaying parts of layers C, D, E and F and their associated structures. The most noticeable feature is the numerous repetitions of layer $\mathrm{E}$ between the intrusions. 


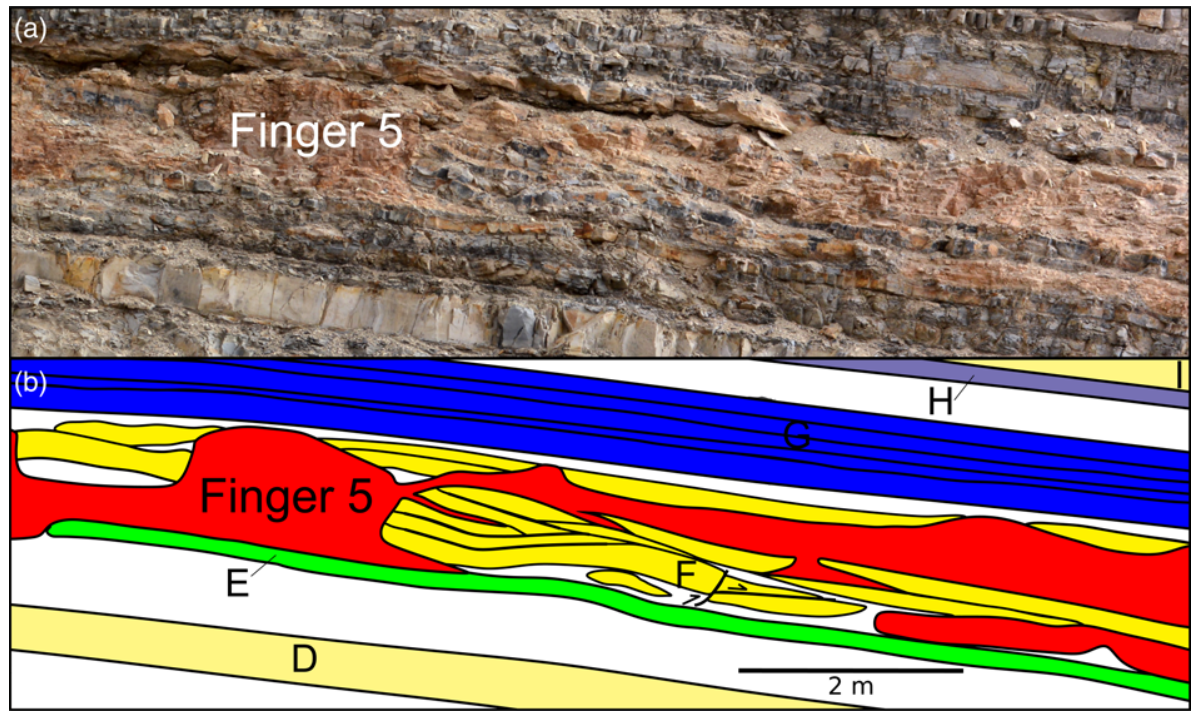

Fig. 6. (a) Detailed orthorectified photograph of the Chihuido outcrop (see location in Fig. 3), displaying parts of finger 5 , and the surrounding structures in the host rock. (b) Detailed map of (a), displaying parts of layers D, E, F, G, H and I and their associated structures. The most noticeable feature is the multiple repetitions of layer. rock ahead of the propagating fingers tips. Qualitatively, the volume of displaced host rock seems to be of the same order as the volume of fingers 1 and 2. We therefore conclude that the emplacement of the small fingers dominantly occurred by pushing their host away (Pollard 1973; Rubin 1993).

The structural map of Figure 3 highlights a significant thickness difference between the two sides of the dyke, below the sill: the sequence between layer D and the sill is two times thicker on the west side of the dyke than on its east side (Fig. 7). One can also notice compressional faults around the dyke, and offset of the layers on the two sides of the dyke (Figs 3 and 7). In contrast, layers G, H and I above the dyke are not offset (Fig. 7). This shows that the observed offset around the dyke is related not to tectonic faulting but to local deformation.

The locally thickened interval between layers $\mathrm{D}$ and $\mathrm{F}$ is the one hosting fingers 1,2, 4 and 5. We infer that this local thickening is a consequence of emplacement of the fingers. It is noticeable that the thicker mudstone layers immediately below (layers C and D) and above (layers G, H and I) do not exhibit undulations that directly mimic the shapes of fingers. We conclude that the thickening owing to the emplacement of the magma is distributed in the layer that hosts the fingers by (1) shortening of mudstone layers ahead of the fingers and (2) ductile flow in the shale. This conclusion is supported by the wedge shape of the interval between layers D and I, suggesting local thickening owing to the pushing of the sill tip, leading to rock wedging as defined by Pollard et al. (1975) and Rubin (1993). These observations highlight that shale acts as a local detachment between competent layers. In addition, we note that layer $\mathrm{D}$ below the fingers exhibits an open monocline towards the east, whereas layers $\mathrm{G}, \mathrm{H}$ and I above the fingers do not. This suggests that the emplacement of the fingers did not produce discernible uplift of the overlying strata.

\section{Comparison with existing emplacement models}

The well-exposed intrusion shapes and structures in the host rock allow us to test and ground truth the relevance of existing magma emplacement models listed in the section 'Sill emplacement mechanism' above (Fig. 1).

Our structural observations are in agreement with the structures expected from both the brittle and ductile flow models (Pollard 1973) and the viscous indenter model (Donnadieu \& Merle 1998; Merle \& Donnadieu 2000; Mathieu et al. 2008; Abdelmalak et al. 2012). On one hand, the intrusion tips of most intrusions have an irregular, subrectangular or blunt shape. In addition, most of the intrusions exhibit substantial and abrupt thickness variations and large thickness-tolength aspect ratios (up to 0.5 for finger 1; Figs 3-5). Such observations are in good agreement with those of, for example, Tweto (1951), Noble (1952), Pollard (1973), Pollard \& Johnson (1973) and Pollard et al. (1975), also referring to sills and fingers emplaced in

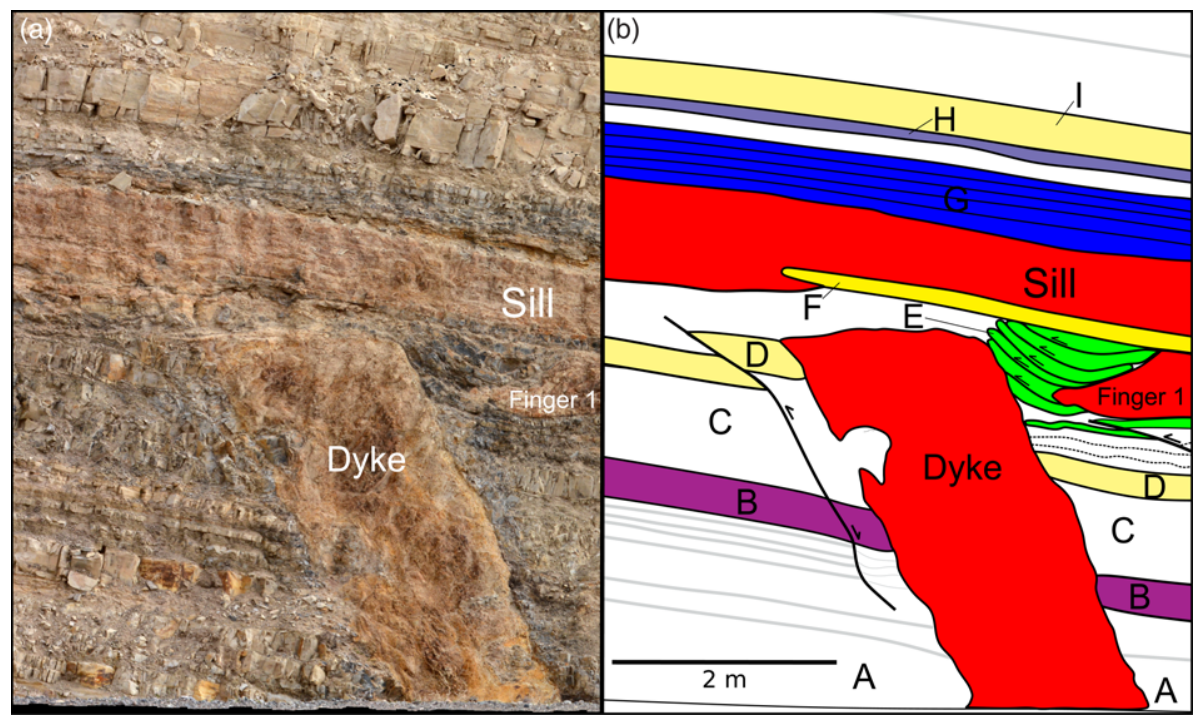

Fig. 7. (a) Detailed orthorectified photograph of the Chihuido outcrop (see location in Fig. 3), displaying the dyke and parts of finger 1 and the sill, and the surrounding structures in the host rock. (b) Detailed map of (a), displaying parts of layers B, D, E, F, G, H and I and their associated structures. The most noticeable features are (1) the multiple repetitions of layer $\mathrm{E}$ between the dyke and finger 1, and (2) the offset of layers B and D on the two sides of the dyke whereas layers G-I are continuous. 


\section{J. B. Spacapan et al.}

shale. On the other hand, the host rock also exhibits structures accommodating intrusion tip propagation that are both brittle faults affecting competent layers and ductile shear bands affecting weak shale layers (Figs 3 - 6). In addition, all these shear structures account for shortening of the host rock ahead of the intrusion tips.

Our structural observations are in disagreement with the tensile elastic fracture mechanism (Fig. 1a). None of the studied intrusions have a sharp tip, and the structures observed in the host rock do not dominantly accommodate tip propagation by tensile or extensional failure. In addition, our observations suggest that inelastic deformation substantially accommodates intrusion propagation.

Our observations do not indicate the presence of fluids and fluid pressure at the intrusion tips, and so do not support the presence of a tip cavity as assumed in the model of Lister (1990b). However, we cannot rule out that a tip cavity disappeared after the propagation halted by the flow of either the shale or the magma into the cavity, which would erase any evidence of it.

Our observations are also in disagreement with the LEFMBarenblatt cohesive zone model of Rubin (1993) (Fig. 1b). This model assumes that intrusion propagation occurs by tensile failure; however, it predicts the occurrence of compressional stresses in the vicinity of the intrusion tip owing to the suction induced by the presence of a tip cavity. This tip suction is expected to pull the host rock ahead of the sill tip toward the tip (fig. 12 of Rubin 1993). The observed structures in the Chihuido outcrop show the opposite; that is, the repeated layer $\mathrm{E}$ ahead of the east tip of finger 2 moved away from the finger tip with respect to the surrounding layers $\mathrm{D}$ and $\mathrm{F}$ (Fig. 5). We infer the same relationship for the layer $\mathrm{G}$ in the plane of the sill (Fig. 4).

All intrusions, even the small fingers 1 and 2, exhibit blunt or sub-rectangular tips, and their emplacement is accommodated by
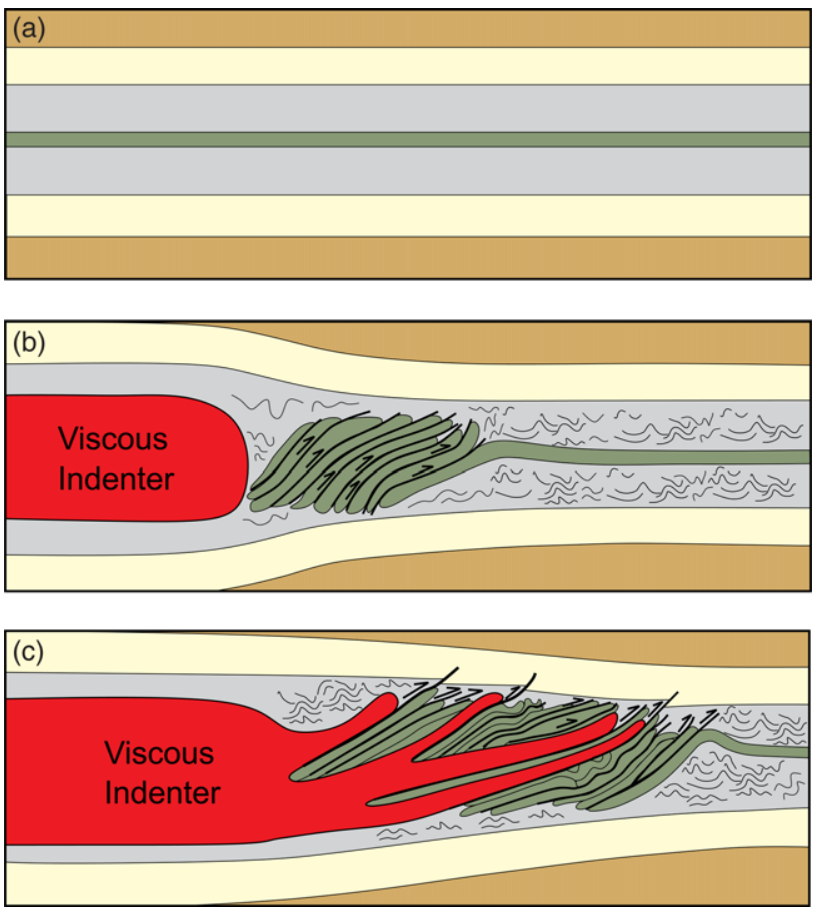

Fig. 8. Sketch showing the emplacement history of the viscous indenter model. (a) Unaltered sedimentary sequence consists of four layers of differing stiffness, thickness and composition. (b) In the initial stage of emplacement, the viscous indenter is characterized by a rounded or blunt tip. As the magma pressure pushes the tip of the sill forward, shear effects are generated, which result in shortening and folding of the country rock. (c) In this manner the sill propagates by indenting the country rock. The end result is a sill with a high radius of curvature of its tip; also, the compression exerted on the country rock generates folds, faults and repetition of layers. substantial inelastic deformation. This is notably true for the small fingers 1 and 2, which pushed away their host rock from a very early stage of their emplacement. This is also in contradiction to the model of Rubin (1993), which assumes that tip blunting can be a late phenomenon, which occurs when (1) sills are significantly large, such that the supposed tip cavity becomes long enough to allow host rock faulting and folding near the intrusion tip, and/or (2) the propagation halts, such that the supposed tip cavity disappears and the magma pressure can bend and deform the host rock and widen the intrusion tip. We thus conclude that Rubin's model, even if it is the most realistic theoretical model, fails to reproduce the firstorder structural features associated with the sills emplaced in shale.

We observed very little and only local fluidization through the outcrop (at the east tip of finger 5). Such a small amount of fluidization suggests that fluidization is a minor phenomenon and cannot explain the emplacement of the studied intrusions. This is in contradiction to the fluidization model proposed by Schofield et al. (2012a) and Jackson et al. (2013) (Fig. 1e). In addition, we found no evidence of fluid overpressures (e.g. veins and beef; Rodrigues et al. 2009; Cobbold et al. 2013) within the host rock at the Chihuido outcrop. This suggests that the model of Gressier et al. (2010), in which sill emplacement is controlled by pore fluid overpressure, does not apply in our study area.

The string of fingers 1-2 and 4-5 (Fig. 3) is similar to the fingers of the Shonkin Sag Sill, Montana described by Pollard et al. (1975). Those researchers concluded that the fingering emplacement process was governed by a Saffman-Taylor instability (Saffman \& Taylor 1958) of an advancing interface between a Newtonian viscous magma and a Newtonian more viscous host rock. Our observations, however, show that the host rock of the fingers and the sill accommodated magma emplacement by brittle and ductile (i.e. plastic) faulting, which shows that the host rock at the studied outcrop did not behave as Newtonian fluid. These fingers thus might be the result of instability of a moving interface between magma and its host rock, but the nature of such instability is different from the Saffman-Taylor instability owing to the non-Newtonian behaviour of the host rock.

\section{Synthesis and discussion}

Intrusions of different sizes on the Chihuido outcrop exhibit distinct structural relations with the deformed host rocks.

(1) The small fingers 1 and 2 were dominantly emplaced by pushing their host rock away, leading to confined rock wedging and imbricate stacks. Consequently, the intrusions have relatively simple shapes, with blunt or sub-rectangular tips (Fig. 8a).

(2) The intermediate-size finger 5 also exhibits intense shortening accommodating the emplacement of its west tip, pushing, shortening and repeating layer F many times (Figs 3 and 6). In contrast to the small fingers 1 and 2, the west tip of finger 5 is much more complex, and exhibits thin magmatic sheets between the repeated slabs of layer F. This structure is very similar to those expected from the brittle faulting model of Pollard (1973). This model states that the intrusion tip initially pushes its host by faulting it and forming rock wedging by local thickening of the shortened host. Because confined rock wedging requires substantial energy (Pollard 1973; Rubin 1993), this process is not sustainable when the intrusion grows, and the magma subsequently flows along the fault planes locally formed in the rock wedge. Following this model, we infer that finger 5 corresponds to a more evolved state of emplacement than fingers 1 and 2 (Fig. 8c).

(3) At the tip of the long sheet-like sill, the deformation at the observable tip also reflects substantial shortening of the host rock layers in the sill plane. Similarly to fingers 1, 2 and 5, the 
observed structures ahead of the sill tip exhibit both brittle faulting of layers E, F and G, and ductile faulting and flow of the surrounding shale layers. In contrast to the fingers, however, the volume of host rock affected by shortening at the sill tip is much smaller than the observed volume of the sill itself. The relatively limited shortening at the tip of the sill suggests that the observed shortening occurred only at a late stage of the sill emplacement, locally at the sill tip. We infer that this configuration corresponds to a more evolved stage of the faulting model of sill emplacement.

These observations suggest the following emplacement sequence (Fig. 8): (1) initial emplacement of a finger dominantly by pushing of its host rock, which deforms by rock wedging; (2) rock wedging stops, and the magma flows along the structures formed during the early rock wedging stage (Pollard 1973); (3) the magma keeps pushing its host by forming local rock wedges that account temporarily for magma tip propagation, before the magma flows along shear structures. This sequence suggests that the emplacement of magma is a dynamic, unsteady process. This mechanism could explain, for example, seismic bursts associated with dyke emplacement in active volcanoes (Hayashi \& Morita 2003; White et al. 2011).

The structural relations between the intrusions allow the history of the relative timing of emplacement to be established. First, the sharp thickness difference on the two sides of the dyke suggests that fingers 1 and 2 were emplaced after the dyke. The presence of the dyke during emplacement of fingers 1 and 2 produced local thickening and compression on the west side of the dyke that could have led to the formation of the observed reverse faults affecting layers C and D (Figs 3 and 7). Second, it is not clear whether the dyke was emplaced after or synchronously with the sill. Although the dyke is separated from the sill by a thin block of shale, it is possible that they are connected in the third dimension, such that the dyke could be the feeder of the sill. If not, the flat tip of the dyke suggests that it was arrested by the presence of the sill, which was emplaced and solidified earlier.

A limitation is that the Chihuido outcrop provides only 2D deformation patterns associated with the sill emplacement. Hansen \& Cartwright (2006a), Thomson (2007) and Schofield et al. (2012b) showed that 3D structures are important for constraining, for example, the flow direction of propagating intrusions. In the studied outcrop, the distribution of the fingers suggests that the dominant magma flow occurred perpendicular to the outcrop, such that the observed structures probably accommodated lateral spreading of the fingers (Pollard et al. 1975; Schofield et al. 2012a). However, the substantial shortening and the repetition of some layers observed at tips of the intrusions is not questionable, regardless of the orientation of the outcrop with respect to the dominant flow direction. Therefore, even if the main flow was not parallel to the outcrop, our conclusion would remain valid.

The host rock at the Chihuido outcrop is dominantly shale, which is known to deform inelastically. In many volcanic basins worldwide, such as the Norwegian margin (e.g. Svensen et al. 2004; Planke et al. 2005), the Karoo Basin (Svensen et al. 2007; Aarnes et al. 2011) and offshore Australia (Jackson et al. 2013), numerous sills and laccoliths were emplaced within weak organicrich shale formations. In the Neuquén Basin, it is documented that sills and laccoliths dominantly formed in shale formations (Rossello et al. 2002; Bermúdez \& Delpino 2008; Rodriguez Monreal et al. 2009; Witte et al. 2012). In addition, recent work has demonstrated that large sills also intruded within salt formations (Svensen et al. 2009; Schofield et al. 2014) or coal layers (Schofield et al. 2012a; Jackson et al. 2013) with evidence of inelastic deformation. We infer that the inelastic emplacement mechanism described in our study can be relevant for numerous sills and laccoliths worldwide.
Our observations show that only the thin layers of the host rock are strongly deformed, whereas the thick layers $(\mathrm{D}, \mathrm{I})$ are poorly, if not, deformed (Figs $3-5$ ). This suggests that the thick layers were too strong to fail, such that they confined the magma emplacement between them. This highlights the strong effect of the layering, and overall the strength contrast between the layers, on the magma emplacement, as demonstrated and discussed by researchers such as Pollard \& Johnson (1973), Rubin (1993), Kavanagh et al. (2006), Galland et al. (2009) and Abdelmalak et al. (2016).

The study area underwent substantial tectonic shortening, therefore one can question whether the observed deformational structures are of tectonic origin or related to the emplacement of the intrusions. Several criteria indicate that the observed structures are not related to regional tectonics: (1) they mostly concentrate at the tips of the intrusions (Fig. 3); (2) they exhibit several, opposite apparent vergences, which are always compatible with the propagation directions of nearby intrusion tips (Figs 4-6); (3) the observed structures affect only the intruded sedimentary layers. For example, the thickening of the sequence between layers D and $\mathrm{F}$ is visible only on the west side of the dyke (i.e. where the intrusions are) but not on the east side of the dyke (Fig. 3). Also, the offset caused by this thickness difference is absent above the sill (Fig. 3). We thus conclude that the observed deformational structures are local and dominantly result from the emplacement of the intrusions.

Duffield et al. (1986) observed compressional structures induced by sill emplacement within shallow, unconsolidated sediments in California. These structures were very similar to those we observed, indicating shortening triggered by the propagation of the sill tip. Duffield et al. (1986) concluded that these structures formed only because the host rock of the sill was not consolidated. However, in our case, the sills intruded in an already compacted formation at $c$. $2 \mathrm{~km}$ depth (Witte et al. 2012). Therefore, the viscous indenter model applies not only to very shallow sill emplacement within unconsolidated sediments, but also more generally to sill emplacement within weak rocks.

\section{Conclusions}

In this paper, we present detailed structural field observations of igneous intrusions and their associated structures in the host rock in a spectacularly exposed outcrop at Cuesta del Chihuido, in the Neuquén Basin, Argentina. The outcrop quality and the fine layering of the host rock (the Agrio Formation) allow us to constrain the dynamics of sill emplacement in shale-dominated units. The main conclusions of our study are summarized by the following points.

(1) Both sheet-shaped sill and fingers observed at the Chihuido outcrop exhibit rounded, blunt or almost rectangular tips.

(2) The propagation of intrusion tips was accommodated by brittle and ductile shortening of the host rock, not by elastic tensile opening.

(3) Our observations suggest that the early stage of magma emplacement occurs by pushing the host rock away and wedging the host rock ahead of intrusion tips, whereas subsequent emplacement occurs by brittle and ductile faulting of the host rock.

(4) The layering in the host rock considerably affects the emplacement of magma: competent layers channel the magma between them, whereas shale layers that host the magma act as local detachments.

(5) Our observations show that the elastic tensile fracture opening mechanism is not relevant for magma emplacement in shale formation; that is, for numerous intrusive complexes in sedimentary basins worldwide.

(6) Our observations do not provide any evidence of the presence of a tip cavity between the tip of the intrusion and the magma 
front, as proposed theoretically by, for example, Lister (1990b) and Rubin (1993).

(7) The structural observations from the Chihuido outcrop suggest that the conceptual viscous indenter model is relevant for magma emplacement in shale formation.

\section{Acknowledgements and Funding}

The fieldwork was supported by a Småforsk grant 'Dynamics of volcanic plumbing systems in sedimentary basins' distributed by the Department of Geosciences, University of Oslo. J.B.S.'s salary is covered by a CONICET-YPF Foundation grant (Grant 2282014000359600). S.P. is supported by a Center of Excellence grant from the Norwegian Research Council to CEED (grant 223272). The work also benefited from the support of the DIPS project (grant 240467) from the Norwegian Research Council. The MicMac photogrammetric software is distributed under the CeC-ILL-B license, implemented at IGN (Institut National de l'Information Géographique et Forestière, France). We gratefully acknowledge the constructive reviews of C. Magee and N. Schofield.

\section{Scientific editing by Carl Stevenson}

\section{References}

Aarnes, I., Svensen, H., Polteau, S. \& Planke, S. 2011. Contact metamorphic devolatilization of shales in the Karoo Basin, South Africa, and the effects of multiple sill intrusions. Chemical Geology, 281, 181-194, https://doi.org/10. 1016/j.chemgeo.2010.12.007

Abdelmalak, M.M., Mourgues, R., Galland, O. \& Bureau, D. 2012. Fracture mode analysis and related surface deformation during dyke intrusion: Results from 2D experimental modelling. Earth and Planetary Science Letters, 359360, 93-105, https://doi.org/10.1016/j.epsl.2012.10.008

Abdelmalak, M.M., Bulois, C., Mourgues, R., Galland, O., Legland, J.B. \& Gruber, C. 2016. Description of new dry granular materials of variable cohesion and friction coefficient: Implications for laboratory modeling of the brittle crust. Tectonophysics, https://doi.org/10.1016/j.tecto.2016.03.003

Baldauf, P., Stephens, G., Nullo, F.E., Combina, A. \& Kunk, M. 1997. Tertiary uplift, magmatism and sedimentation of the Andes, Southern Mendoza Province, Argentina. Geological Society of America, Abstracts with Programs, 29, 48

Bermúdez, A. \& Delpino, D.H. 2008. Concentric and radial joint systems within basic sills and their associated porosity enhancement, Neuquén Basin, Argentina. In: Thomson, K. \& Petford, N. (eds) Structure and Emplacement of High-Level Magmatic Systems. Geological Society, London, Special Publications, 302, 185-198, https://doi.org/10.1144/SP302.13

Bunger, A.P. \& Cruden, A.R. 2011. Modeling the growth of laccoliths and large mafic sills: Role of magma body forces. Journal of Geophysical Research, 116, B02203, https://doi.org/10.1029/2010jb007648

Cartwright, J. \& Hansen, D.M. 2006. Magma transport through the crust via interconnected sill complexes. Geology, 34, 929-932.

Chevallier, L. \& Woodford, A. 1999. Morpho-tectonics and mechanism of emplacement of the dolerite rings and sills of the western Karoo, South Africa. South African Journal of Geology, 102, 43-54

Chevallier, L., Goedhart, M. \& Woodford, A. 2001. The influence of dolerite sill and ring complexes on the occurrence of groundwater in the Karoo fractured aquifers: a morpho-tectonic approach. Report 937, Water Resource Commission.

Chevallier, L., Gibson, L.A., HNhleko, L.O., Woodford, A.C., Nomquphu, W. \& Kippie, I. 2004. Hydrogeology of fractured-rock aquifers and related ecosystems within the Qoqodala dolerite ring and sill complex, Great Kei catchment, Eastern Cape. Report 1238, Water Resource Commission.

Cobbold, P.R. \& Rossello, E.A. 2003. Aptian to recent compressional deformation, foothills of Neuquén Basin, Argentina. Marine and Petroleum Geology, 20, 429-443.

Cobbold, P.R., Zanella, A., Rodrigues, N. \& Løseth, H. 2013. Bedding-parallel fibrous veins (beef and cone-in-cone): Worldwide occurrence and possible significance in terms of fluid overpressure, hydrocarbon generation and mineralization. Marine and Petroleum Geology, 43, 1-20, https://doi.org/10. 1016/j.marpetgeo.2013.01.010

Combina, A.M. \& Nullo, F.E. 2005. Tertiary volcanism and sedimentation in the southern Cordillera principal, Mendoza, Argentina. 6th International Symposium on Andean Geodynamics, Barcelona, Spain, 174-177.

Donnadieu, F. \& Merle, O. 1998. Experiments on the indentation process during cryptodome intrusions: New insights into Mount St. Helens deformation. Geology, 26, 79-82.

Duffield, W.A., Bacon, C.R. \& Delaney, P.T. 1986. Deformation of poorly consolidated sediment during shallow emplacement of a basalt sill, Coso Range, California. Bulletin of Volcanology, 48, 97-107, https://doi.org/10. 1007/bf01046545

Galerne, C.Y., Galland, O., Neumann, E.R. \& Planke, S. 2011. 3D relationships between sills and their feeders: evidence from the Golden Valley Sill Complex (Karoo Basin) and experimental modelling. Journal of Volcanology and Geothermal Research, 202, 189-199, https://doi.org/10.1016/j.jvolgeores. 2011.02.006
Galland, O. \& Scheibert, J. 2013. Analytical model of surface uplift above axisymmetric flat-lying magma intrusions: Implications for sill emplacement and geodesy. Journal of Volcanology and Geothermal Research, 253, 114-130, https://doi.org/10.1016/j.jvolgeores.2012.12.006

Galland, O., Planke, S., Neumann, E.R. \& Malthe-Sørenssen, A. 2009 Experimental modelling of shallow magma emplacement: Application to saucer-shaped intrusions. Earth and Planetary Science Letters, 277, 373-383.

Galland, O., Burchardt, S., Hallot, E., Mourgues, R. \& Bulois, C. 2014 Dynamics of dikes versus cone sheets in volcanic systems. Journal of Geophysical Research: Solid Earth, 2014JB011059, https:/doi.org/10.1002/ 2014jb011059

Galland, O., Bertelsen, H.S. et al. 2016. Application of open-source photogrammetric software MicMac for monitoring surface deformation in laboratory models. Journal of Geophysical Research: Solid Earth, https://doi. org/10.1002/2015JB012564

Giambiagi, L., Ghiglione, M., Cristallini, E. \& Bottesi, G. 2009. Kinematic models of basement/cover interaction: Insights from the Malargüe fold and thrust belt, Mendoza, Argentina. Journal of Structural Geology, 31, 1443-1457, https://doi.org/10.1016/j.jsg.2009.10.006

Graveleau, F., Malavieille, J. \& Dominguez, S. 2012. Experimental modelling of orogenic wedges: A review. Tectonophysics, 538-540, 1-66, https://doi.org/ 10.1016/j.tecto.2012.01.027

Gressier, J.B., Mourgues, R., Bodet, L., Matthieu, J.Y., Galland, O. \& Cobbold, P.R. 2010. Control of pore fluid pressure on depth of emplacement of magmatic sills: An experimental approach. Tectonophysics, 489, 1-13.

Gudmundsson, A., Marinoni, L.B. \& Marti, J. 1999. Injection and arrest of dykes: implications for volcanic hazards. Journal of Volcanology and Geothermal Research, 88, 1-13.

Gulisano, C.A. \& Gutiérrez Pleimling, A.R. 1995. Field Guide, the Jurassic of the Neuquén Basin: B, Mendoza Province. Secretaría de Minería de la Nación and Asociación Geológica Argentina, Buenos Aires.

Hansen, D.M. \& Cartwright, J.A. 2006a. Saucer-shaped sill with lobate morphology revealed by 3D seismic data: implications for resolving a shallow-level sill emplacement mechanism. Journal of the Geological Society, London, 163, 509-523, https://doi.org/10.1144/0016-764905-073

Hansen, D.M. \& Cartwright, J.A. 2006 $b$. The three-dimensional geometry and growth of forced folds above saucer-shaped igneous sills. Journal of Structural Geology, 28, 1520-1535.

Hayashi, Y. \& Morita, Y. 2003. An image of a magma intrusion process inferred from precise hypocentral migrations of the earthquake swarm east of the Izu Peninsula. Geophysical Journal International, 153, 159-174, https://doi.org/ 10.1046/j.1365-246X.2003.01892.x

Hubbert, M.K. \& Willis, D.G. 1957. Mechanics of hydraulic fracturing. AIME Transactions, 210, 153-168.

Jackson, C.A.L., Schofield, N. \& Golenkov, B. 2013. Geometry and controls on the development of igneous sill-related forced-folds: a 2D seismic reflection case study from offshore southern Australia. Geological Society of America Bulletin, 125, 1874-1890.

Jaeger, J.C., Cook, N.G.W. \& Zimmerman, R.W. 2009. Fundamentals of Rock Mechanics. Blackwell, Oxford.

Jamtveit, B., Svensen, H., Podladchikov, Y.Y. \& Planke, S. 2004. Hydrothermal vent complexes associated with sill intrusions in sedimentary basins. In Breitkreuz, C. \& Petford, N. (eds) Physical Geology of High-level Magmatic Systems. Geological Society, London, Special Publications, 233-241, https:// doi.org/10.1144/GSL.SP.2004.234.01.15

Jamtveit, B., Kobchenko, M., Austrheim, H., Malthe-Sørenssen, A., Røyne, A. \& Svensen, H. 2011. Porosity evolution and crystallization-driven fragmentation during weathering of andesite. Journal of Geophysical Research, 116, B12204, https://doi.org/10.1029/2011jb008649

Kavanagh, J.L., Menand, T. \& Sparks, R.S.J. 2006. An experimental investigation of sill formation and propagation in layered elastic media. Earth and Planetary Science Letters, 245, 799-813.

Kavanagh, J.L., Menand, T. \& Daniels, K.A. 2013. Gelatine as a crustal analogue Determining elastic properties for modelling magmatic intrusions. Tectonophysics, 582, 101-111, https://doi.org/10.1016/j.tecto.2012.09.032

Kay, S.M., Burns, W.M., Copeland, P. \& Mancilla, O. 2006. Upper Cretaceous to Holocene magmatism and evidence for transient Miocene shallowing of the Andean subduction zone under the northern Neuquén basin. In: Kay, S.M. \& Ramos, V. (eds) Evolution of an Andean Margin: A Tectonic and Magmatic View from the Andes to the Neuquén Basin $\left(35^{\circ}-39^{\circ}\right.$ S lat.). Geological Society of America, Special Papers, 407, 19-60.

Leanza, H.A. 2009. Las principales discordancias de Mesozoico de la Cuenca Neuqina según observaciones de superficie. Revista del Museo Argentino de Ciencias Naturales, 11, 145-184.

Leanza, H. \& Hugo, C. 1978. Sucesión de ammonites y edad de la Formación Vaca Muerta y sincrónicas entre los paralelos 35 y 40 ls Cuenca NeuquinaMendocina. Revista de la Asociación Geológica Argentina, 32, 248-264.

Legarreta, L., Kozlowski, E. \& Boll, A. 1981. Esquema estratigráfico y distribución de facies del Grupo Mendoza en el ámbito surmendocino de la Cuenca Neuquina. Actas VIII Congreso Geológico Argentino, 389-409.

Lister, J.R. 1990a. Buoyancy-driven fluid fracture. Similarity solutions for the horizontal and vertical propagation of fluid-filled cracks. Journal of Fluid Mechanics, 217, 213-239.

Lister, J.R. 1990b. Buoyancy-driven fluid fracture. The effects of material toughness and of low-viscosity precursors. Journal of Fluid Mechanics, 210, 263-280. 
Lister, J.R. \& Kerr, R.C. 1991. Fluid-mechanical models of crack propagation and their application to magma transport in dykes. Journal of Geophysical Research, 96, 10049-10077.

Maccaferri, F., Bonafede, M. \& Rivalta, E. 2010. A numerical model of dyke propagation in layered elastic media. Geophysical Journal International, 180, 1107-1123, https://doi.org/10.1111/j.1365-246X.2009.04495.x

Magee, C., Hunt-Stewart, E. \& Jackson, C.A.L. 2013. Volcano growth mechanisms and the role of sub-volcanic intrusions: Insights from 2D seismic reflection data. Earth and Planetary Science Letters, 373, 41-53, https://doi.org/10.1016/i.eps1.2013.04.041

Magee, C., Jackson, C.A.L. \& Schofield, N. 2014. Diachronous sub-volcanic intrusion along deep-water margins: insights from the Irish Rockall Basin. Basin Research, 26, 85-105, https://doi.org/10.1111/bre.12044

Magee, C., Muirhead, J.D. et al. 2016. Lateral magma flow in mafic sill complexes. Geosphere, 12, 809-841, https://doi.org/10.1130/ges01256.1

Manceda, R. \& Figueroa, D. 1995. Inversion of the Mesozoic Neuquén Rift in the Malargüe Fold and Thrust belt, Mendoza, Argentina. In: Tankard, A.J., Suárez, R. \& Welsink, H.J. (eds) Petroleum Basins of South America. AAPG, Memoirs, 62, 169-182.

Mathieu, L., van Wyk de Vries, B., Holohan, E.P. \& Troll, V.R. 2008. Dykes, cups, saucers and sills: Analogue experiments on magma intrusion into brittle rocks. Earth and Planetary Science Letters, 271, 1-13.

McCaffrey, K.J.W. \& Petford, N. 1997. Are granitic intrusions scale invariant? Journal of the Geological Society, London, 154, 1-4, https://doi.org/10.1144/ gsjgs.154.1.0001

Menand, T. \& Tait, S. 2002. The propagation of a buoyant liquid-filled fissure from a source under constant pressure: an experimental approach. Journal of Geophysical Research, 107, https://doi.org/10.1029/2001JB000589.

Merle, O. \& Donnadieu, F. 2000. Indentation of volcanic edifices by the ascending magma. In: Vendeville, B., Mart, Y. \& Vigneresse, J.-L. (eds) Salt, Shale and Igneous diapirs in and around Europe. Geological Society, London, Special Publications, 174, 43-53, https://doi.org/10.1144/GSL.SP. 1999.174.01.03

Michaut, C. 2011. Dynamics of magmatic intrusions in the upper crust: Theory and applications to laccoliths on Earth and the Moon. Journal of Geophysical Research, 116, B05205, https://doi.org/10.1029/2010jb008108

Nermoen, A., Galland, O., Jettestuen, E., Fristad, K., Podladchikov, Y.Y., Svensen, H. \& Malthe-Sørenssen, A. 2010. Experimental and analytic modeling of piercement structures. Journal of Geophysical Research, 115, B10202, https://doi.org/10.1029/2010jb007583

Noble, J.A. 1952. Evaluation of criteria for the forcible intrusion of magma Journal of Geology, 60, 34-57, https://doi.org/10.2307/30057011

Nullo, F.E., Stephens, G., Combina, A., Dimieri, L., Baldauf, P., Bouza, P. \& Zanettini, J.C.M. 2005. Hoja geológica 3569-III/3572-IV Malargüe, provincia de Mendoza. Servicio Geológico Minero Argentino. Instituto de Geología y Recursos Minerales, Buenos Aires.

Petford, N., Cruden, A.R., McCaffrey, K.J.W. \& Vigneresse, J.L. 2000. Granite magma formation, transport and emplacement in the Earth's crust. Nature, 408, 669-673

Pierrot-Deseilligny, M. \& Paproditis, N. 2006. A multiresolution and optimizationbased image matching approach: an application to surface reconstruction from SPOT5-HRS stereo imagery. International Archives of Photogrammetry, Remote Sensing and Spatial Information Sciences, 36 (Part 1/W41), 73-77.

Planke, S., Rasmussen, T., Rey, S.S. \& Myklebust, R. 2005. Seismic characteristics and distribution of volcanic intrusions and hydrothermal vent complexes in the Vøring and Møre basins. In: Doré, A.G. \& Vining, B.A. (eds) Proceedings of 6th Petroleum Geology Conference. Geological Society, London, 833-844, https://doi.org/10.1144/0060833

Pollard, D.D. 1973. Derivation and evaluation of a mechanical model for sheet intrusions. Tectonophysics, 19, 233-269, https://doi.org/10.1016/0040-1951 (73) $90021-8$

Pollard, D.D. 1987. Elementary fracture mechanics applied to the structural interpretation of dikes. In: Halls, H.C. \& Fahrig, W.F. (eds) Mafic Dyke Swarms. Geological Association of Canada, Special Papers, 34, 5-24.

Pollard, D.D. \& Johnson, A.M. 1973. Mechanics of growth of some laccolithic intrusions in the Henry Mountains, Utah, II. Bending and failure of overburden layers and sill formation. Tectonophysics, 18, 311-354.

Pollard, D.D., Muller, O.H. \& Dockstader, D.R. 1975. The form and growth of fingered sheet intrusions. Geological Society of America Bulletin, 86, 351-363, https://doi.org/10.1130/0016-7606(1975)86<351:tfagof $>2.0$.co;2

Polteau, S., Ferré, E.C., Planke, S., Neumann, E.-R. \& Chevallier, L. 2008a. How are saucer-shaped sills emplaced? Constraints from the Golden Valley Sill, South Africa. Journal of Geophysical Research, 113, https://doi.org/10.1029/ 2008JB005620

Polteau, S., Mazzini, A., Galland, O., Planke, S. \& Malthe-Sørenssen, A. $2008 b$. Saucer-shaped intrusions: occurrences, emplacement and implications. Earth and Planetary Science Letters, 266, 195-204.

Rivalta, E., Böttinger, M. \& Dahm, T. 2005. Buoyancy-driven fracture ascent: Experiments in layered gelatine. Journal of Volcanology and Geothermal Research, 144, 273-285.

Rodrigues, N., Cobbold, P.R., Loseth, H. \& Ruffet, G. 2009. Widespread bedding-parallel veins of fibrous calcite ('beef') in a mature source rock (Vaca Muerta Fm, Neuquén Basin, Argentina): evidence for overpressure and horizontal compression. Journal of the Geological Society, London, 166, 695-709, https://doi.org/10.1144/0016-76492008-111
Rodriguez Monreal, F., Villar, H.J., Baudino, R., Delpino, D. \& Zencich, S. 2009. Modeling an atypical petroleum system: A case study of hydrocarbon generation, migration and accumulation related to igneous intrusions in the Neuquén Basin, Argentina. Marine and Petroleum Geology, 26, 590-605, https://doi.org/10.1016/j.marpetgeo.2009.01.005

Roman, D.C., Power, J.A., Moran, S.C., Cashman, K.V., Doukas, M.P., Neal, C. A. \& Gerlach, T.M. 2004. Evidence for dike emplacement beneath Iliamna Volcano, Alaska in 1996. Journal of Volcanology and Geothermal Research, 130, 265-284.

Rossello, E.A., Cobbold, P.R., Diraison, M. \& Arnaud, N. 2002. Auca Mahuida (Neuquén basin, Argentina): A Quaternary shield volcano on a hydrocarbonproducing substrate. In: 5th ISAG, Extended Abstracts, Toulouse, 549-552.

Rosu, A.-M., Pierrot-Deseilligny, M., Delorme, A., Binet, R. \& Klinger, Y. 2015. Measurement of ground displacement from optical satellite image correlation using the free open-source software MicMac. ISPRS Journal of Photogrammetry and Remote Sensing, 100, 48-59, https://doi.org/10.1016/j. isprsjprs.2014.03.002

Rubin, A.M. 1993. Tensile fracture of rock at high confining pressure: Implications for dike propagation. Journal of Geophysical Research: Solid Earth 98, 15919-15935, https://doi.org/10.1029/93jb01391

Rubin, A.M. 1995. Propagation of magma-filled cracks. Annual Review of Earth and Planetary Sciences, 23, 287-336.

Saffman, P.G. \& Taylor, G. 1958. The penetration of a fluid into a porous medium or Hele-Shaw cell containing a more viscous liquid. Proceedings of the Royal Society of London, Series A, 245, 312-329, https://doi.org/10.1098/rspa.1958. 0085

Sagasti, G. 2000. La sucesión rítmica de la Formación Agrio (Cretácico inferior) en el sur de la provincia de Mendoza, y su posible vinculación con Ciclos de Milankovitch. Revista de la Asociación Argentina de Sedimentología, 7, 1-22.

Sagasti, G. 2005. Hemipelagic record of orbitally-induced dilution cycles in Lower Cretaceous sediments of the Neuquén Basin. In: Veiga, G.D., Spalletti, L.A., Howell, J.A. \& Schwartz, E. (eds) The Neuquén Basin, Argentina: A Case Study in Sequence Stratigraphy and Basin Dynamics. Geological Society, London, Special Publications, 252, 231-250, https://doi.org/10.1144/ GSL.SP.2005.252.01.11

Schofield, N., Stevenson, C.T. \& Reston, T. 2010. Magma fingers and host rock fluidization in the emplacement of sills. Geology, 38, 63-66, https://doi.org/ 10.1130/g30142.1

Schofield, N., Brown, D.J., Magee, C. \& Stevenson, C.T. $2012 a$. Sill morphology and comparison of brittle and non-brittle emplacement mechanisms. Journal of the Geological Society, London, 169, 127-141, https://doi.org/10.1144/ 0016-76492011-078

Schofield, N., Heaton, L., Holford, S.P., Archer, S.G., Jackson, C.A.L. \& Jolley, D.W. 2012b. Seismic imaging of 'broken bridges': linking seismic to outcropscale investigations of intrusive magma lobes. Journal of the Geological Society, London, 169, 421-426, https://doi.org/10.1144/0016-76492011-150

Schofield, N., Alsop, I., Warren, J.K., Underhill, J.R., Lehne, R., Beer, W. \& Lukas, V. 2014. Mobilizing salt: magma-salt interactions. Geology, 42, https://doi.org/10.1130/G35406.1

Spacapan, J.B., Galland, O., Leanza, H.A. \& Planke, S. 2016. Control of strikeslip fault on dyke emplacement and morphology. Journal of the Geological Society, London, 173, 573-576, https://doi.org/10.1144/jgs2015-166

Svensen, H., Planke, S., Malthe-Sorenssen, A., Jamtvelt, B., Myklebust, R., Eldem, T.R. \& Rey, S.S. 2004. Release of methane from a volcanic basin as a mechanism for initial Eocene global warming. Nature, 429, 542-545.

Svensen, H., Planke, S., Chevallier, L., Malthe-Sorenssen, A., Corfu, F. \& Jamtveit, B. 2007. Hydrothermal venting of greenhouse gases triggering Early Jurassic global warming. Earth and Planetary Science Letters, 256, 554-566.

Svensen, H., Planke, S., Polozov, A.G., Schmidbauer, N., Corfu, F., Podladchikov, Y.Y. \& Jamtveit, B. 2009. Siberian gas venting and the endPermian environmental crisis. Earth and Planetary Science Letters, 277, 490-500, https://doi.org/10.1016/j.eps1.2008.11.015

Symonds, P.A., Planke, S., Frey, O. \& Skogseid, J. 1998. Volcanic evolution of the Western Australian continental margin and its implications for basin development. In: Purcell, P.G. \& Purcell, R.R. (eds) The Sedimentary Basins of Western Australia: Proceedings of the Petroleum Exploration Society of Australia Symposium, Petroleum Exploration Society of Australia, Perth, 33-54.

Taisne, B. \& Tait, S. 2009. Eruption versus intrusion? Arrest of propagation of constant volume, buoyant, liquid-filled cracks in an elastic, brittle host. Journal of Geophysical Research: Solid Earth, 114, B06202, https://doi.org/ 10.1029/2009jb006297

Takada, A. 1990. Experimental study on propagation of liquid-filled crack in gelatin: shape and velocity in hydrostatic stress condition. Journal of Geophysical Research, 95, 8471-8481.

Thomson, K. 2004. Volcanic features of the North Rockall Trough: application of visualisation techniques on $3 \mathrm{D}$ seismic reflection data. Bulletin of Volcanology, 67, 116-128.

Thomson, K. 2007. Determining magma flow in sills, dykes and laccoliths and their implications for sill emplacement mechanisms. Bulletin of Volcanology, 70, 183-201.

Thomson, K. \& Hutton, D. 2004. Geometry and growth of sill complexes: insights using 3D seismic from the North Rockall Trough. Bulletin of Volcanology, 66, 364-375.

Trude, J., Cartwright, J., Davies, R.J. \& Smallwood, J. 2003. New technique for dating igneous sills. Geology, 31, 813-816. 


\section{J. B. Spacapan et al.}

Tweto, O. 1951. Form and structure of sills near Pando, Colorado. Geological Society of America Bulletin, 62, 507-532.

Uliana, M., Dellape, D. \& Pando, G. 1977. Análisis estratigráfico y evaluación del potencial petrolífero de las Formaciones Mulichinco, Chachao y Agrio. Cretácico Inferior de las Provincias de Neuquén y Mendoza. Petrotecnia, 16, $31-46$.

Vergani, G.D., Tankard, A.J., Belotti, H.J. \& Welsink, H.J. 1995. Tectonic evolution and paleogeography of the Neuquén basin, Argentina. In: Tankard, A.J., Suárez, R. \& Welsink, H.J. (eds) Petroleum Basins of South America. AAPG, Memoirs, 383-402.
Walker, G.P.L. 1975. Intrusive sheet swarms and the identity of Crustal Layer 3 in Iceland. Journal of the Geological Society, London, 131, 143-159, https://doi. org/10.1144/gsjgs.131.2.0143

White, R.S., Drew, J., Martens, H.R., Key, J., Soosalu, H. \& Jakobsdóttir, S.S 2011. Dynamics of dyke intrusion in the mid-crust of Iceland. Earth and Planetary Science Letters, 304, 300-312, https://doi.org/10.1016/j.epsl.2011. 02.038

Witte, J., Bonora, M., Carbone, C. \& Oncken, O. 2012. Fracture evolution in oilproducing sills of the Rio Grande Valley, northern Neuquén Basin, Argentina. AAPG Bulletin, 96, 1253-1277, https://doi.org/10.1306/10181110152 